\title{
Social disease and social science: the intellectual influence of non-medical research on policy and practice in the Colonial Medical Service in Tanganyika and Uganda
}

\author{
Shane Doyle
}

In scholarship since the mid-1980s colonial medicine has often been described as a key element in the imperial state's attempt to understand, monitor and control subject communities. Moreover, scholars have noted how colonial hagiographies emphasised doctors' intimate knowledge of local attitudes and practices, shaped by humanitarian concern and long service, extolled the technological mastery of the imperial scientist, and praised the power of the colonial state to transform communities, legitimised and facilitated by medical expertise. ${ }^{1}$ These assertions and ambitions, however, were not always realised. Medical interventions were frequently shaped by racial or political rather than objective, scientific motivations, and their consequences could be destabilising rather than hegemonic. Moreover, doctors were not always blind to the limits of their understanding of indigenous societies. As colonial states matured, and medical officers' attention moved beyond the needs of European officials and the local servants, soldiers and police who sustained them, so their lack of knowledge of the underlying causes of disease among the wider indigenous population provoked increasing concern. Some conditions, defined as social diseases, demanded particular attention, because their incidence was recognised as being shaped by the imperfectly understood nature of local societies. This chapter will examine the nature of colonial knowledge, and the formulation of medical interventions, by focusing on colonial reactions to two social diseases in two neighbouring societies: sexually transmitted infections (STIs) in Buhaya in colonial Tanganyika and malnutrition in Buganda, the largest kingdom in Uganda. ${ }^{2}$

In particular, the chapter will consider the role played by non-medical 
academic researchers, who were affiliated to the colonial state, in shaping medical understanding of the context within which these two particular medical problems existed. Government anthropologists and a variety of social scientists attached to the East African Institute for Social Research, funded by the British Colonial Office, provided vital input and scientific legitimacy to the colonial medical departments' attempts to radically reform African sexual and family life. These nonmedical experts encouraged clinicians to understand local behavioural patterns in terms of African reactions to universalistic paradigms such as modernisation or attachment theory, as well as tribal particularism. Significantly, this development worked against the liberal tendencies of many late colonial doctors, who were eager to separate disease susceptibility from broad-based assumptions associating race with certain behaviours, and instead continued to foster a tendency to pathologise African social life through generalised discourses. ${ }^{3}$

\section{Orgies of drink and women: ethnography, morality and STIs in Buhaya}

When British officials displaced their German predecessors in Buhaya, in north-west Tanganyika, during the First World War, they found themselves in possession of a territory with several unusual features. The introduction of the plantain or cooking banana a thousand or more years before had permitted the development of dense, semi-permanent settlements. ${ }^{4}$ Descriptions of the villages that ran along Buhaya's eastern ridges, dating from the period of German rule, are characterised by an appreciation of the superficially familiar nature of this intensively cultivated landscape. Within Haya settlements surpluses were produced, food was readily available, paths were shaded and swept, huts were large and solidly constructed and plots were separated from their neighbours by tall, meticulously maintained hedges. ${ }^{5}$ By contrast, the onset of British rule in 1916 introduced a new culture of colonial criticism and reformism which targeted not only local land husbandry but also Haya behaviour. In part, this new interventionism reflected a positive appreciation of Buhaya's economic potential. The young colonial state of Tanganyika, determined to wean itself off metropolitan subsidy as quickly as possible, saw in Buhaya a source of significant revenue. Early investment in coffee nurseries and a degree of coercion soon brought spectacular results. By 1923 Buhaya's coffee exports were already worth $£ 113,387$. By 1928 their value had more than quadrupled. Coffee was so well suited to eastern Buhaya's farming system that almost all the land that supported bananas was quickly intercropped with robusta coffee. The sudden prosperity that landholders enjoyed 
from the early 1920s had some unexpectedly far-reaching repercussions. Chiefly patronage became devalued, the transfer of resources to the younger generation was delayed and new inequalities within marital relationships began to emerge. By the mid-1920s these various sources of social tension had all become associated with one peculiarly emotive issue, sexual behaviour. This was because sex workers had come to rival coffee as Buhaya's most famous export. Anxiety about prostitution justified a tendency towards radical interventionism in the realm of sexuality that was sustained by evolving political, moral and economic debates right through to decolonisation. ${ }^{6}$

Ethnographers and officials alike associated the exceptional frequency of commercial sex work among Haya women with the new, coffee-related commercialism of Haya society. According to the anthropologists Southall and Gutkind, the enhancement of the material value of female labour inflated bridewealth to such a degree that husbands began to behave toward their wives 'as headmen rather than as lovers, keeping them slaving to make up for the expense incurred to get them'. ${ }^{7}$ Colonial officials believed that wives, their sense of self-worth increasingly shaped by school and church, in turn demanded material recognition of the market value of their labour. The 'silk, perfume and high heeled shoes' worn by the mistresses of colonial officials and Indian merchants in the district capital, Bukoba, were reportedly coveted by rural women as early as the 1920s. Household heads' refusal to satisfy this craving for luxury supposedly gave unmarried younger men an opportunity 'by gifts of clothes and money [to] render the women independent of their husbands'. It is striking how lacking in patriarchal condemnation European comments on Haya sexual behaviour in this period were. According to the 1925 district annual report, women 'proceeding to Nairobi and Kampala rather than submitting to the old social order of things in Bukoba' was inevitable, given male elders' greed, the inequitable nature of Haya marriage and the 'idleness and promiscuous immorality of the younger men'. ${ }^{8}$

However, the assumption that declining marital stability and fidelity had made sexually transmitted diseases endemic within Buhaya limited the sympathy felt for women. STIs were blamed for both the low productivity and the low fertility of the Haya, so that sexual misconduct was viewed explicitly as a threat to tax revenues. Given that Buhaya was one of only a handful of areas of significant economic development in interwar Tanganyika, inaction was not an option. ${ }^{9}$

This tendency towards interventionism which characterised the British colonial state in Buhaya, then, was partly based on the significance of the district's coffee industry, and partly derived from the perception that the Haya were undermining not only their own health 
but also that of the fragile colonial economy as a result of their sexual immorality and the exceptionally high prevalence of STIs. In the early 1920s Buhaya, like societies across the border in Uganda, was described by local Europeans as suffering from nearly universal syphilitic infection. ${ }^{10}$ Whereas medical opinion grew much more cautious in Uganda from the mid-1920s, in Buhaya the belief that STIs were so prevalent that the population faced possible extinction was still expressed into the mid-1950s. ${ }^{11}$ In part this simply reflected the relative absence of external critical analysis of medical policy, but the sense that the Haya suffered extreme levels of STI infection did have some statistical basis, even if the data recorded were of uneven reliability. In 1925 syphilis accounted for 31 per cent and gonorrhoea for 7 per cent of all out-patient diagnoses at Bukoba hospital. In 192842 per cent of all cases treated in Buhaya's many dispensaries and dressing stations were diagnosed as syphilis, three and a half times greater than the national average. The number of syphilis cases per capita also rose significantly between the wars. In 1938 Bukoba treated by far the largest number of STI patients of all the hospitals in the Territory, accounting for a sixth of Tanganyika's gonorrhoea cases and a tenth of all syphilis cases. In the early 1940s a quarter of women attending ante-natal clinics had strongly positive Kahn tests for syphilis, and one in five Haya recruits for military service were diagnosed as suffering from gonorrhoea. A third of all operations at Bukoba hospital were external urethrotomies to relieve strictures that were assumed to result from untreated gonorrhoea. ${ }^{12}$ The British Army's venereologist in East Africa encountered 'an amazing amount of gonorrhoea and many phagedenic penile lesions' in Bukoba in 1944, the latter probably a reference to chancroid. In the early 1950s the East African Medical Survey, having adopted extremely careful diagnostic methods, found that 6.8 per cent of men in three communities surveyed had gonorrhoea, and 17.1 per cent of the entire population surveyed had strongly positive Kahn test results..$^{13}$ It seems clear that STIs were a much greater problem here than in most East African societies.

For European officials, sex work was a symptom of a larger malaise affecting Haya society. In 1947 Elspeth Huxley, inspired by Goethe's tale of 'die Geister, die ich rief', toured East Africa in order to investigate how indigenous societies had responded to the uncontrollable 'sorcerer's magic' of European culture and technology. Whereas much of the region seemed to her doomed to dearth and desertification, Buhaya's banana-coffee permaculture had brought about a utopia of stable incomes, relative ease and food security. 'The Bahaya ${ }^{14}$ seem to have achieved, in large measure, that state towards which our own society is so painfully struggling: the enjoyment of long hours, indeed 
weeks, of leisure, freedom from fear and want, and the satisfaction of material needs at the expense of the minimum of effort.' While drawing on the Arcadian literary tradition in her description of Buhaya, Huxley's writing also made deliberate reference to contemporary claims about what could be achieved by the new technocratic, welfarist developmentalism of the post-war Empire. But Bukoba's district administration, also employing ancient and modern tropes, corrected her assumption that the Haya had already entered the brave new world which was proving so difficult for the post-war government at home to create. Combining conservative scepticism about the character-weakening effect of welfare with long-established racial preconceptions, officials reminded Huxley that one of William Beveridge's five giants obstructing social reconstruction was idleness, and warned of the degrading consequences of leisure on the African psyche. 'This happy state, at least in their soft tropical climate, seems to have corroded their will to work and rotted away their self-respect and morals.' The Haya were the victims of "'too much prosperity"'. ${ }^{15}$

Throughout Africa, the sense that 'civilisation' and modernity were undermining social and moral structures was commonplace in the writing of administrators, missionaries and psychiatrists. ${ }^{16} \mathrm{New}$ colonial states everywhere had argued that Africans should be coerced into the cash economy by universal taxation and, if necessary, forced labour, justified by the assumption that there existed a reservoir of underutilised labour within African societies, where women seemed to do most of the work. ${ }^{17}$ By the mid-colonial period the destabilising effects of such innovations were the subject of much concern. In some parts of the continent, among the Bemba for example, monetisation itself was thought by observers to have undermined key aspects of local economic and social structures. ${ }^{18}$ Colonial-era criticisms of, or concerns about, African prosperity, though, were not so common. The Haya were distinctive because their morally enervating idleness was viewed as a product of the low labour demands associated with both their traditional food staple and their new cash crop. Efficiency, so valued by Europeans when justifying colonial development and governance, was, it seems, inappropriate for Africans.

District reports had defined immorality as a by-product of rising cash income and indolence as early as 1925. The response to Huxley's admiring comments in 1947 were rehearsed many times over the years. Haya were regularly criticised for refusing to grow their coffee in the textbook manner, to monocrop or to mulch neatly. The same, frustrating lack of faith in European expertise was displayed in their rejection of colonial agronomists' advice on how to treat banana weevil, nematodes and panama disease, in the belief, largely correct, it now seems, 
that the declining productivity of their staple plantain crop was caused by colonial policies in the first place, and that the treatments on offer only made matters worse. Above all, they refused to put more land under coffee once its natural limit in the long-established villages of the eastern ridges was reached in the mid-1930s. Europeans were outraged that young men seemingly preferred to wait around in eastern Buhaya to inherit their fathers' plots rather than open up new coffee farms of their own. As early as 1932 colonial commentators had become convinced that the eastern ridges had reached their carrying capacity, and that young men were unable to marry while they waited for their inheritance. Officials, themselves self-sacrificing overseas servants of a colonising society, despaired that young Haya men rejected the opportunity to marry and move out west to the empty, fertile lands around Lake Ikimba, in favour of the seductive pleasures of the village. This lack of pioneering spirit, further evidence of the moral weakness of the Haya, was so aggravating because the stagnation of Bukoba's coffee production undermined not only the development of Tanganyika as a whole, but officials' own career progression. ${ }^{19}$ In 1935, at its peak, a quarter of the coffee produced in East Africa came from Buhaya. Soon, though, optimism that the Haya would drag the rest of Tanganyika out of backwardness dissipated, and successive district reports bemoaned local resistance to scientific farming methods and declining tax revenues. ${ }^{20}$ Buhaya's densely cultivated villages, the most productive land in Tanganyika, discomforted the officials who served the British colonial state. To them, the rotting mulch and humid shade, the high hedges and twisting paths, symbolised darkness and corruption, and provided a perfect environment for the nurturing of sexual affairs. ${ }^{21}$

Buhaya remained one of colonial Tanganyika's showcase districts, but its prosperity, literacy and political sophistication disturbed many of the officials who actually worked there. Bukoba was regarded as a 'difficult' place to govern. One administrator complained that its 'complex, vociferous and mass-educated population' was interested in only two issues, education and STIs, and observed that 'they suffer from both'. The tone of the memoirs of another district commissioner, Tim Harris, darkened in the chapter entitled 'Bukoba - the ultimate test'. Though forewarned of 'the never-satisfied ambitions and prideful sloth of the Bahaya as a tribe', he nonetheless found that 'the unremitting tension in Bukoba, coupled with the volume of work and the long hours of argument ... bred in me a near-paranoia'. Fatigue and frustration were the lot of Bukoba administrators, their creative energy dissipated in the adjudication of court appeals. A quarter of Haya adult males were involved in legal disputes in any one year. That such enthusiasm for the law was attributed by district officers to the Haya's misuse of their 
education, wealth and free time, rather than being taken as a mark of support for the pax Britannica, is indicative of the nature of colonial rule. ${ }^{22}$

In 1938, in response to requests from Buhaya's district administration and medical officer that some action be taken in response to the apparent threat of depopulation, three of Tanganyika's most experienced ethnographers were charged with investigating Haya sub-fertility. The leader of the team, Arthur Culwick, was regarded as one of the colonial administration's experts in ethnography and native affairs. His wife, Geraldine, who had studied anthropology at Oxford and had subsequently acquired expertise in nutrition and demography, accompanied him. ${ }^{23}$ The third member of the team was Hans Cory, the Tanganyika administration's full-time anthropologist, who was believed to have an unparalleled understanding of the workings of African societies.

Cory and the Culwicks, on the basis of large-scale surveys, a study of local administrative and medical records and extensive interviewing, confirmed the local perception that "The Bahaya are threatened with extinction as the result of venereal disease. ${ }^{24}$ Hans Cory explained the dissipation of Haya males in clichéd terms, their cultural integrity having been lost with their twin roles of herder and warrior. 'Because of the pacification of the country by the Europeans and the advent of rinderpest the men lost the purpose of their life and with it the concrete basis of their tribal customs and institutions.' Arthur Culwick too held that the 'breaking up of Bantu society' explained Buhaya's crisis of masculinity and morality, but, drawing on a larger concern about detribalisation, explicitly blamed social collapse on the very nature of colonial rule. As he saw it, traditional forms of discipline had been undermined by European libertarianism and the atomising, degrading economic independence provided by cash cropping. Indirect rule had permitted local chiefs to deflect European guidance through 'passive resistance and courteous obstruction', causing Haya to mock 'our administration as effete and incapable of even making the most highly paid native official do any work'. The result was 'the complete breakdown of sexual morality in the tribe. The Bahaya could hardly achieve a greater degree of promiscuity if they tried.' Haya wives, regarded 'as an agricultural machine and a domestic drudge' by their 'drunken, lazy and generally dissolute' menfolk, had quite reasonably chosen a life of prostitution. For Culwick, these women symbolised the corrupting, deracinating nature of colonial capitalism: they 'sell themselves in Bukoba during the coffee season and then migrate to Mwanza or Uganda for the cotton season'. The sexual freedom and endemic STIs which resulted had caused 'a much greater degree of neurosis than I have seen in any other tribe', and contributed to Bukoba's notorious 
difficulty as an administrative posting. Freedom from compulsion had made Haya men unruly subjects as well as bad husbands. Culwick's solution was to force the Haya to control sexual misbehaviour within their communities. He was 'unable to see that any able-bodied man has any right whatsoever to fritter away his life in an orgy of drink and women', and advocated coercion not only to improve public health and morality but also because it would, he believed, bring 'beneficial psychological changes ... which would make the tribe much easier to deal with' ${ }^{25}$

Cory, instructed by Culwick to work out the details of the programme of compulsion, in late 1938 proposed the establishment of highly intrusive village-level societies or viama. These would facilitate the distribution of moral propaganda, the organisation of STI testing and treatment and the introduction of improving entertainment. Primarily, though, they would 'separate the healthy from the sick', with viama membership dependent on a negative STI test. Members would wear a badge, inform on neighbours who were infected with STIs and agree not to pay or receive money for sex. The real target of the campaign would be 'the worst offenders, the prostitute and the men of similar character. These mobile incubators of bacilli have to be rendered innocuous as soon as possible.' Cory anticipated that isolation and harassment would prompt 'a lot of the village beauties [to] emigrate', so he planned to establish quarantine stations at Bukoba port and the Uganda border where all female travellers would undergo examination and treatment for STIs. ${ }^{26}$

Cory and Culwick's proposals came to nothing in the short term. Culwick's condemnation of indirect rule and cash cropping was unlikely to win central government approval. However, when the 1948 census showed that Buhaya was one of the few areas in East Africa whose population had failed to increase since 1931, its district commissioner argued that this confirmed 'the trend foretold by Culwick ... the population is rapidly disappearing due to VD [venereal disease], prostitution and the general break-up of family life'. ${ }^{27}$

In response to these repeated warnings of imminent demographic collapse, Tanganyika's government requested that the newly established East African Medical Survey (EAMS) select Buhaya as one of its survey sites. The EAMS obliged, keen to understand why the Haya had not responded appropriately to the opportunities offered by colonial development. 'Here we have a productive area with a high rainfall, much money from cash crops, with available all the advantages of civilization, e.g. good educational facilities, first-class medical care and attention with a good general hospital, and readily available expert advice on agricultural, veterinary and other matters, with a central 
thoroughly efficient administration in command. And yet the tribe is dying.' The explanation, once again, was idleness and immorality. While the survey's 1953 annual report noted that there was no correlation between the results of STI tests and fertility levels, blaming high levels of divorce for Haya sub-fertility, the final EAMS report in 1954 returned to familiar ground. 'Extra-marital intercourse' and consequent infection with gonorrhoea were hypothesised to be the primary causes of the low reproduction rate. Only when the Haya were shown 'the evil of their ways' might their demographic problems be resolved. ${ }^{28}$

That the EAMS recommendation that Buhaya required a programme of intensive STI treatment and reproductive health information would be acted upon was far from inevitable. Colonial governments were wary of interfering in the realm of sexuality, and across the border in Uganda coercive interventions had drawn such embarrassing attention from London that STI policy there had become distinctly low key by the 1950s. Several factors combined to ensure that the EAMS's reports were put into effect.

Most obviously the enthusiasm of the medical department and of the colonial and chiefly administrations for an aggressive response to the STI problem in Buhaya was shaped by the exceptional prominence of sexually transmitted infections within the medical statistics. In addition, the belief that many Haya were unaware that gonorrhoea was transmitted sexually gave impetus to plans for disease control. Public health campaigns that focused primarily on correcting misinformation were always considered to have a reasonable likelihood of success. ${ }^{29}$ Just as important, Tanganyika's medical department had already provided a model for the mass eradication of treponemal disease in the form of its yaws control programme, which treated 137,112 people in 1930 alone. ${ }^{30}$ The potential of mass compulsory STI treatment on a local scale was recognised within the Tanganyika administration during the Second World War, moreover. In 1943 the director of medical services announced that it was 'the intention of this Department to carry out after the war campaigns against special diseases in selected areas of heaviest incidence, e.g. against VD in Bukoba'. Wartime experience had demonstrated the advantages of compulsory STI treatment within a captive population. ${ }^{31}$

Haya opinion had also begun to demand radical intervention to control STIs. Haya leaders put the district administration under intense pressure during the late 1940s to improve the medical treatment of STIs and to prevent Haya women from leaving for the cities. The official colonial response that STIs were social diseases which required reform within Haya society, and that freedom of movement was guaranteed for all subjects, was interpreted as a 'deliberate policy designed to reduce 
the population of the District'. Local administrators, evidently influenced by the Culwicks' suggestion that the healthy and sick should be segregated and that all who were ill should be compelled to complete a full course of treatment, were sympathetic, but constrained by central policy. ${ }^{32}$ Tensions built as the STI issue became caught up with a wider debate about the use of Buhaya's coffee cess, a development tax which the colonial state had consistently employed to encourage the Haya to improve their techniques of coffee cultivation. As this involved more work with no immediate returns, the policy was deeply unpopular. The arrival of the EAMS offered the district administration a way out of the impasse. The pilot scheme's success convinced the Haya that the mass use of penicillin could eradicate gonorrhoea and syphilis. The district commissioner hoped that the use of the coffee cess to cover the high cost of such a programme would cause the Haya to take greater responsibility for their own health and reform their sexual behaviour. 'If not, the Haya would learn at their own expense that a purely medical approach will not work, and they would in future have only themselves, instead of government, to blame.' At the very least, a programme on such a scale would require the upgrading of all medical services in the district, so that the health and efficiency of the Haya would inevitably improve. ${ }^{33}$

The proposed campaign quickly took shape, partly because of the support of the EAMS. It seems that the EAMS offered at least implicit support to the concept of mass compulsory treatment because its medical researchers, like Cory and the Culwicks before it, believed that while prostitution had to be controlled, in general terms women were the victims of Buhaya's STI problem. As one of the project leaders remembered 'the men spent most of their time womanizing and drinking ... The women were made to do all the work ... All the revenue from the coffee went to the husband ... It is not surprising that several of the women revolted at such treatment and ran away.' Most female infections were believed to stem from their husbands' infidelity, and, due to the difficulty of diagnosing gonorrhoea in women, the disease had typically already damaged the female reproductive system by the time women sought treatment, if they did so at all. ${ }^{34} \mathrm{~A}$ voluntaristic campaign, then, would leave most female sufferers untreated.

The success of the STI control programme lay in the decision to adopt a single-shot high-dosage injection of procaine penicillin as the standard treatment for both gonorrhoea and syphilis. The initial strategy was to treat all residents in the vicinity of each treatment centre who reported a history of STI infection or low fertility, dispensing with time-consuming testing. The medical teams relied on forceful persuasion, pressing local chiefs and missionaries to encourage attendance. As 
one participant recalled, 'They brought the medicine there, and people were being injected compulsorily. I saw it ... There was really meaningful propaganda going on, and the force behind it in the villages was kind of hand in glove, but chiefs were encouraging their people. ${ }^{35}$ Only in the mid-1950s, as the campaign matured, did testing begin to take on more prominence. The control programme in its early years was peripatetic, aiming to cure all infections in a defined area before moving on. By 1957 the decision to allow penicillin to be injected at all twentythree of Buhaya's dispensaries saw the campaign settle into a routine of offering easily available cures for all new infections. The popularity of the STI control programme rested in large part on the decision to send the most able recently qualified Tanganyikan doctors to work in Buhaya. No longer dependent on outsiders with ethnographic expertise to provide expert knowledge of the social aspects of disease causation, the Colonial Medical Service instructed its own indigenous staff to use their social contacts to help bring down the prevalence of STIs. ${ }^{36}$ These local doctors' view of the STI problem owed much to the analysis of previous writers such as Cory and the Culwicks, one advocating 'a complete change in the structure and customs of the tribe, first through the emancipation of the women and then perhaps by introducing a change in the economic pattern so that the young men share the work with the women and marry early'. Otherwise Haya women would continue to marry older men but 'get their satisfaction elsewhere' or become sex workers 'to lead a free independent life' ${ }^{37}$ But indigenous doctors like Charles Mtawali and Vedast Kyaruzi had a realistic awareness of the difficulty of effecting mass sexual behavioural change. Their focus instead was on the practical goals of persuading local sex workers to agree to voluntary registration and monthly doses of penicillin, and ensuring that STI control became part of a wider push to improve public health in the district, so that significant investment was made in female education, anti-malarial measures, water sanitation and the provision of nutritional health information. ${ }^{38}$ Over the next ten to fifteen years, STI incidence fell significantly and, at least partly as a consequence, fertility rose sharply and divorce rates declined by a quarter. ${ }^{39}$

The role of the Culwicks' and Cory's reports in shaping subsequent medical policy should not be exaggerated. Their findings and recommendations were referenced by district administrators and by members of the EAMS, and the prominence of these native affairs specialists added weight to their proposals. But it is clear from the writings of Hans Cory and Arthur Culwick how heavily influenced they were by local discourse. There are striking similarities in the language used in Culwick's final report and the apocalyptic writings of local Lutheran missionaries in the same year. It seems likely, moreover, that the 
Culwicks' assertion that sexual misconduct was the primary cause of population decline in Buhaya was at least partly derived from local European opinion, given that moral criticism was largely absent from their earlier work on depopulation in Ulanga. What Cory and the Culwicks added above all to Buhaya's STI debate was the authority of scientific expertise and apparent statistical proof. But the power of academic advisors, it seems, was greatest when their policy recommendations fitted neatly with, and were shaped by, local medical and popular opinion. The EAMS, for example, sought the assistance of the East African Institute of Social Research to analyse Haya problems of reproduction, but seems to have been little influenced by the findings of Priscilla Reining, one of the Institute's anthropologists. Reining considered that the role of STIs in causing Buhaya's demographic stagnation was exaggerated, and that the criticism of Buhaya's wealth and low labour input jarred with the development goals of the Tanganyikan state. She was disregarded. Discordant external expert opinion, it appears, could easily be ignored by medical practitioners. ${ }^{40}$

\section{'The semi-sophisticated Baganda'41: malnutrition and modernity in central Uganda}

It may seem surprising to compare STIs with malnutrition. STIs, after all, were diseases which were the subject of exceptionally intrusive and authoritarian medical interventions, justified by the danger to public health that they posed and their assumed origins in personal misconduct. But diseases linked to diet, like those associated with sexuality, were acknowledged to be profoundly social conditions, shaped by both entrenched custom and the cultural and moral transformation associated with colonialism, capitalism and Christianity. Controlling such diseases required an intimacy of knowledge of Africans' domestic and private lives that was considered unnecessary in relation to conditions such as malaria or measles. Acquiring such a depth of understanding of local attitudes and behaviours in Buganda did not require the kind of intense, project-like investigations seen in Buhaya with Hans Cory and the Culwicks' work in the late 1930s or the EAMS in the 1950s. After all, the Ganda were one of the most closely examined societies in colonial Africa. In the early twentieth century, a remarkable range of amateur ethnographies written by European administrators and missionaries, and self-descriptive accounts of customs and beliefs by indigenous intellectuals, constructed the Ganda as an African people who were exceptionally open to new influences from the outside world. ${ }^{42}$ In the middle decades of the twentieth century a series of professionally trained anthropologists and psychologists, all interested in the Ganda's 
response to the forces of modernisation, produced a succession of ground-breaking works. ${ }^{43}$ Though these social scientists rarely focused specifically on nutrition, recurring themes in their work were the state of the Ganda family and Ganda methods of childrearing. These issues formed the bridge between medical and social scientists who were equally interested in analysing the healthfulness of Ganda society as it came under what were perceived to be intense strains in the middle decades of the twentieth century. It is the collaboration that resulted that forms the focus of the second half of this chapter.

Once a showpiece of the British Empire, Buganda by the 1940s had fallen out of favour. European administrators complained that its famous Agreement of 1900 obstructed economic development, its mailo system of semi-freehold land tenure was blamed for creating a rentier class responsible for agricultural inefficiency in the countryside and squalor in town, and Ganda politics were increasingly dominated by populist, anti-colonial agitators who undermined the collaboration which had brought Buganda and the British wealth and regional domination. ${ }^{44}$ Yet this period, which brought such administrative disillusionment, witnessed a flowering of medical and social science research. The war years had interrupted the normal leave pattern of the Ugandan Medical Service, with the enforced stabilisation of staffing facilitating new kinds of sustained study. In addition Kampala's Mulago Hospital welcomed a series of visiting research-oriented doctors, on leave or secondment from their military duties in the region. New ideas were introduced, permanent links were established with British hospitals and research institutions and a cohort of ambitious young doctors made plans to return on a permanent basis once the war ended. Many of these incomers were attracted by Uganda's long-established activity in the field of public health, but on their return sought to build upon this pattern of sporadic, top-down sanitary interventions by establishing a more community-based approach, aiming ultimately at the creation of a network of health centres.

Simultaneously, Britain's more intensive exploitation of African resources after 1945 was accompanied by investment not only in expanded medical provision but also in higher education. In particular the decision was taken to set up the East African Institute of Social Research (EAISR) in 1947, based in Kampala and attached to Makerere College, which was soon to be affiliated to the University of London. EAISR was established with the explicit aim of monitoring how East Africans were adapting to intensifying pressures to produce for the market, participate in new forms of political organisation and adopt Western concepts of law, ethics and attainment. Initially EAISR's academic staff were little involved with their medical counterparts. 
The identification of malnutrition as the defining medical problem affecting the Ganda was entirely the product of Mulago-based research. Initially, as Michael Worboys has shown, malnutrition attracted the attention of colonial medical departments between the wars only due to the realisation that improved African diets would increase the value of 'the native as an economic factor' ${ }^{\prime}{ }^{45}$ In Uganda the growing emphasis on preventive medicine during the 1930s, combined with deepening colonial concern about overstocking and the impact of soil erosion, resulted in the first nutritional surveys and the beginnings of local medical research into dietary imbalances. By the late 1940s, though, a group of talented doctors became convinced that kwashiorkor, or protein-energy malnutrition, was extremely common in Uganda. One, Hugh Trowell, would later write that kwashiorkor was 'the commonest cause of death in tropical Africa' in the mid-colonial period. The existence of the condition, though, was only generally accepted when atrophy of the pancreas, rendering advanced cases incapable of digesting food, was identified by Uganda's leading pathologist, J.N.P. Davies. ${ }^{46}$

Kwashiorkor, in the Ga language, refers to the illness suffered by an older child when it is displaced by a newborn. ${ }^{47}$ Among the Ganda, this phenomenon was known as obwosi, and was associated directly with the maternal neglect of the older child, and more precisely with the abrupt cessation of breastfeeding that it experienced, consequent on the mother's falling pregnant again. ${ }^{48}$ Obwosi assumed so much significance among medical researchers because of their awareness of the Ganda's unusual pattern of mortality. In the later colonial period, census results showed that as many children died between their first and fifth birthdays in Buganda as during infancy. In particular, Ganda children seemed especially vulnerable as they approached their first birthday and during their second year of life. This trait was first quantified in the late 1940s by Hebe Welbourn, one of the pioneers of community medicine in Uganda. Welbourn had initially come to Uganda as a medical missionary, but, put off by what she perceived to be the systemic overdiagnosis of syphilis, she transferred to the Colonial Medical Service in order to attempt to convince Ganda mothers of the value of preventive medicine. Her child welfare clinics grew in popularity and allowed her to conduct longitudinal studies of the progress made by young children in Buganda. The results of her work were first reported in her MD thesis of 1952, aptly titled 'The Danger Period during Weaning ${ }^{\prime}{ }^{49}$

Welbourn pioneered the use of growth charts to track children's weight and height, finding that Ganda children were born small, grew rapidly up to the age of five to six months due to their unlimited access to breastmilk, and then their growth stalled, sometimes due to 
their first infection with malaria, but more often, she believed, due to the inadequacy of Ganda weaning methods. Babies were expected to eat a diet similar to that of adults, except even more carbohydrate heavy. For many small children the introduction of lumpy, indigestible foods, severely lacking in protein, coincided with their removal from their mothers in order to live with relatives. This cultural practice, she observed, was designed to help mothers and babies cope with the strains associated with a woman's subsequent pregnancy, but, among the peri-urban communities with which she worked, the difficulty of feeding a growing family in a primarily cash-based economy had accelerated the relocation of children. The psychological upset which followed, coinciding with new infections and exposure to inappropriate weaning foods, was, she believed, a direct cause of kwashiorkor. Welbourn's most significant finding was that the majority of the nominally healthy children who attended her child welfare clinics suffered from mild protein-energy malnutrition. ${ }^{50}$

By the late 1940s medical researchers based at Mulago had made a series of crucial discoveries which transformed understanding of the aetiology of kwashiorkor, explaining both why it seemed to affect such a large proportion of the Ganda population to some degree and why, in its acute form, it was so frequently fatal. ${ }^{51}$ But finding an effective treatment still proved elusive, and, as Jennifer Tappan has shown, high mortality rates, highly invasive techniques of medical investigation and experimentation and a systemic failure to explain interventions adequately caused growing disquiet amongst many Ganda. Rumours of sorcery abounded, parents regularly removed their children from medical care before treatment was completed and, when riots broke out in 1949 due primarily to Ganda farmers' and workers' sense of political and economic marginalisation, biomedical researchers working on kwashiorkor were targeted. Medical research was suspended for a period, and when it resumed, a more cautious, culturally sensitive approach was adopted. This, then, formed part of the context which made medical researchers here particularly receptive to engagement with social scientists. ${ }^{52}$ Further encouragement towards interdisciplinary engagement came in 1952. Crucially, the development of an effective treatment made the focus of new kwashiorkor research turn towards prevention. That researchers would devote so much energy to investigating the cultural causes of malnutrition was due in part to the publication of a report entitled 'Medical Research in the Tropics' by the chief executive of the United Kingdom's Medical Research Council, Sir Harold Himsworth. Himsworth, keen to integrate medical research at home and in the Empire, argued strongly against the environmental determinism that, in his view, had caused tropical medicine to be 
categorised almost as a separate discipline. His advocacy, and close involvement with Uganda's nutritional research, directed attention towards the social aspects of kwashiorkor. ${ }^{53}$

As a consequence, through the 1950s and early 1960s doctors in the Colonial Medical Service such as Dick Jelliffe and Hebe Welbourn worked collaboratively, and at times dialectically, with a number of social scientists. These anthropologists and psychologists tended to view childhood malnutrition as a symptom of a wider malaise, Africans' imperfect adaptation to colonial modernity. ${ }^{54}$ This was a topic of general concern to British policy makers in Africa from the late 1930s as a series of strikes, damning reports of the destructive social impact of labour migration and revolts such as Mau Mau pushed colonial governments towards a policy of labour stabilisation and family reform. Labour contracts were extended; training and unionisation were encouraged, to a degree; key urban workers were granted a family wage and provided with family housing; and landholdings were consolidated. At its most extreme this attempt to remould African communities sought to break urban workers' social, economic and cultural ties with their rural kinship networks and to encourage the displacement of the extended with the nuclear family. Unsurprisingly, this attempt to reorient Africans towards a world where wealth was to be invested in direct descendants rather than distant kin, urban women would confine themselves to the domestic sphere and political activity would be deradicalised, had very limited success. ${ }^{55}$

Scholars attached to EAISR tended not to see their function as one of proposing specific policy interventions. Rather, theirs was a responsive, analytical role. And one of the recurring concerns of the late colonial period was the perceived weakening of Ganda familial bonds. Colonial officials, indigenous political leaders and local newspapers regularly complained about the growing instability of Ganda marriage, the rise in female-headed households, declining parental supervision of children and a concomitant increase in the frequency of premarital sexual activity. ${ }^{56}$ This discourse shaped the research of a number of social scientists during the 1950s and early 1960s, whose conclusions in turn influenced medical analyses of the causation of kwashiorkor.

Social scientists' most significant contribution to the medical understanding of kwashiorkor derived from their work on the impact of fostering. This was a theme of particular importance for child psychologists in the post-war period, due to the influence of John Bowlby's work on how babies formed emotional attachments to their mothers, and thus how humans became socialised. Bowlby encouraged two researchers with interests in this phenomenon to examine it in nonWestern contexts. Accordingly, Marcelle Geber and, several years later, 
Mary Ainsworth came to Buganda, primarily because of Buganda's reputation as a society in which small children were routinely abruptly weaned and separated from their mothers. ${ }^{57}$ Geber and Ainsworth independently observed remarkable physical and mental precocity among breastfed Ganda infants, whose motor, language and social skills were weeks or months ahead of their European peers'. Geber explained this phenomenon in terms of the relative lack of anxiety experienced by pregnant Ganda women and the 'loving and warm behaviour of the mothers' after babies were born. 'Before the child is weaned, the mother's whole interest is centred on him. She never leaves him, carries him on her back - often in skin-to-skin contact - wherever she goes, sleeps with him, feeds him on demand at all hours of the day or night, forbids him nothing and never chides him.' Both researchers, though, reported that the effect of maternal separation on the Ganda toddler was extreme. The resultant trauma and, in some cases, subsequent neglect by foster carers appeared to directly lead to a loss of these children's advanced physical state, and severe unhappiness, frequently demonstrated through anorexia or bulimia. ${ }^{58}$

The practice of fostering was examined not only by psychologists, but also by the anthropologist Audrey Richards, whose concern was with the social impact of the remarkably high incidence of fostering in Buganda. Her surveys suggested that a majority of Ganda children under the age of twelve were sent away from home at some point to live with relatives and learn good behaviour and clanship, a practice that had become more common due to marriage break-up, education, infertility and the economic power of elders in Buganda, who held most of the kingdom's land. Parents found it difficult to refuse requests for fosterage, and often actively encouraged it, hoping that a guardian's weaker emotional tie to a child would make it easier to impose discipline. Older children were increasingly sent to stay with relatives who lived in close proximity to a good primary school, while the ending of a sexual relationship commonly led to the rehousing of children, either because a single mother was unable to support them alone or because of the antipathy of an incoming step-parent. While Richards was careful to emphasise that many older children considered that being sent to live with relatives for several years had been beneficial for their character formation, and noted moreover that some children developed a close bond with their surrogate parents, her findings overall added to the sense that trauma was a common feature of Ganda childhood. Even where children were not sent or taken away from their mothers, social scientists argued that their psychological state was still often disturbed by the absence of a father figure. In 1957 the anthropologist Aidan Southall wrote of the strain experienced by urban families in 
Kampala, due to endemic marital instability and the large proportion of households which were headed by single women. While a lack of male role models was hardly uncommon across urban Africa, according to Southall it was especially problematic in Buganda, due to the relative vagueness of its extended family relationships. ${ }^{59}$

A recurring theme in the work of Ainsworth, Geber and Southall was that the systemic inadequacy of children's upbringing in Buganda created a self-propelling momentum, so that damaged children grew up to be damaged and destructive parents. Researchers believed that the separation of a child from its parents and of a husband from his wife contributed to a range of social ills in Buganda: child neglect, the inadequacy of sex education, the supposed inability of many Ganda to establish enduring relationships of affection. ${ }^{60}$ Crucially, these assumptions filtered through to medical researchers seeking to explain the severity of malnutrition among children. The paediatrician Hebe Welbourn, in a childrearing manual aimed at a mass Ganda audience, wrote that 'children who change homes several times ... never really trust anybody and seem to make difficulties in every home they stay in for long, including their own homes when they grew [sic] up and marry'. A few years later, in 1963, she noted that

unfortunately it would appear that a large proportion of Baganda children do not establish strong primary maternal attachments. Indeed attachments of all kinds seem to be very tenuous. After weaning, the child may pass into a home in which there is no older person with whom he can make contact. He may be continually uprooted, passing from one home to another throughout his childhood. By adolescence he has very likely ceased to regard himself as belonging in any particular home. It is probably this lack of personal attachments, rather than weaning, per se, which presents the greatest difficulty in personality development of Baganda and which probably underlies such increasing prevalent social problems as promiscuity and marital instability, crimes associated with theft, and the revival of witchcraft and tribal religion.

Welbourn was far from atypical among medical writers in this period. Together with Fred Bennett and Dick Jelliffe, leading researchers into community health and malnutrition, she argued that

all over Africa, increasing segments of communities find themselves involved in the process of rapid cultural transition.... The new town dwellers ... are usually quite unprepared for a life so different from their tight-knit village society. Overcrowded, substandard housing, an unfamiliar money economy, and especially disruption of rural tribal customs and regulations, tend to lead to increased incidence of illegitimate, unwanted or abandoned children, of venereal disease, and of prostitution and delinquency among juveniles. ${ }^{61}$ 
Doctors seeking to reduce the incidence of malnutrition in Buganda struggled to adopt a consistent line on the question of modernisation. Early writings tended to blame above all Ganda traditional weaning practices for the remarkable frequency of kwashiorkor in this society, noting that educated parents introduced their children to a wider range of solids than the mass of plantain and sweet potato that was typical fare in less 'modern' households. But as the 1950s progressed the focus of criticism shifted to two groups. One was referred to as the semieducated, who supposedly aspired to a Western life-style and accordingly adopted bottle-feeding, yet lacked the standards of hygiene and income necessary to keep bottles clean and provide formula milk in more than 'homeopathic' quantities. The combination of under-nutrition and recurrent gastroenteritis that resulted was associated with particularly severe levels of mortality. The second group were single mothers, who had separated from the fathers of their young children and, unable to cope financially with the responsibilities of motherhood, weaned their babies prematurely so that they could be passed on to a relative at a younger age than had traditionally been the practice. Again, this was regarded as having particularly destructive outcomes. The early critique of stubborn traditionalism quickly morphed into one of a skewed or partial modernisation which corrupted both traditional and Western practices. This most familiar of social scientific concerns in colonial Africa survived through to independence. ${ }^{62}$

\section{Conclusion}

Medical policy is never developed in intellectual or political isolation, shaped purely by the research and practice of healthcare workers. This is perhaps particularly true of what can be termed social diseases, conditions where medical specialists require the input of other disciplines in order to better understand the context within which disease-causing behaviours emerge, and where officials and interest groups are especially likely to press for specific medical interventions. Certainly in Buhaya popular outrage and political leaders' sense of self-preservation helped ensure that the EAMS recommendations of the 1950s were acted upon. In Buganda, medical responses to malnutrition during the colonial period were shaped not just by the interests of a range of medical actors and funders, including the World Health Organization, UNICEF and the Medical Research Council, but also by the findings of a cohort of anthropologists and psychologists, and by Buganda's royal government, which passed laws aimed at restricting what were regarded as the most damaging forms of fostering. Social scientists, then, were not the only external influences on medical policy in these societies, 
and their counsel was ignored when it jarred with received medical or political opinion. But the collaboration between doctors and scholars from other specialisms could be significant, as it was in Buganda in the 1950s, when for several years local programmes against malnutrition concentrated heavily on the perceived problems of Ganda parenting.

Colonial contexts were particularly likely to encourage crossfertilisation. Colonial governance prioritised stability and projected control, but it was profoundly insecure. The maintenance of distance between ruler and ruled obstructed the acquisition of knowledge of the desires and fears of the subject population, on which effective government depends. The quest for information tended to draw different strands of the colonial structure together, as seen for example in Lord Hailey's African surveys, or E.B. Worthington's studies of scientific research across the Empire. It also caused dependencies to seek to learn from each other, with Buhaya, for example, repeatedly mimicking Buganda's experiments in STI policy. This was no guarantee of best practice, however, for, as we have seen, post-war Buhaya adopted strategies that had been quietly abandoned north of the border. ${ }^{63}$ While the ignorance of imperial regimes was in part a function of their limited resources, their corresponding advantage was that the scale of the state was sufficiently small for inter-departmental cooperation to be easily achieved, if the will existed. The district team, which required administrative and technical staff to meet regularly, was a common feature across British colonial Africa, sustained in large part by the simplicity of the state. Scale, along with shared backgrounds and worldviews, facilitated the interpersonal relationships on which knowledge sharing depended. Mulago and Makerere, medical and social science, were sited on neighbouring hills in Kampala, and their staff lived in the same neighbourhoods, socialised in the same clubs and often drew on similar liberal influences.

And yet, alongside the undoubted humanitarianism of the researchers who have featured in these case studies, the moralising tendency of the Colonial Medical Service in this region should also be emphasised. Medical discourse relating to STIs in Buhaya was remarkable for the consistency of its critique of Haya sexual attitudes and behaviour, whether the doctors involved were European or African, specialists or generalists. In Buganda, the early twentieth-century fixation with syphilis was shaken by metropolitan criticism of poor diagnostic practice, payments to chiefs who informed doctors which of their subjects were infected and the compulsory examination and treatment of villagers in front of their neighbours. By the 1950s Ganda sexuality had in theory become more a topic for analysis than for simple condemnation as social scientists were set the task of identifying the underpinnings of 
what was now termed dysfunctional rather than immoral behaviour. ${ }^{64}$ Yet medical concerns about endemic malnutrition and systemic failures of parenting quickly drew upon long-standing critiques of Ganda sexuality, which was pathologised in new ways in the late colonial period, this time with the backing of science rather than Christianity. Now its excesses were attributed primarily to a malfunctioning family system, characterised by absent fathers, bereft mothers and rootless children. Kwashiorkor was thus viewed as a symptom of a more fundamental flaw within Ganda society, in which ill-considered tradition and destabilising modernisation undermined the socialisation of the young.

The severity of this wide-ranging criticism of indigenous society is surprising, given the Ugandan Medical Service's comparative reputation for social liberalism, evidenced by its early Africanisation, its recruitment of a number of South Africans whose community-focused health provision had jarred with the apartheid regime and its prioritisation of maternal and child health provision. Part of the explanation for this apparent contradiction seems to lie in the power of universalist theories which, for example, heightened expectations that Ganda would suffer a destructive form of cultural schizophrenia as they experienced modernisation, and that their children would be invariably traumatised by practices such as fostering. Many medical personnel, meanwhile, combined social liberalism with engrained assumptions about racial difference and, indeed, inferiority. It was not uncommon for researchers into kwashiorkor to wonder whether nutritional deficiencies on an individual or racial level accounted for what they perceived to be Africans' "'backwardness"', "'stupid[ity]"', or "'poor work performance ${ }^{\prime \prime \prime} .{ }^{65}$ But researchers were shaped as much by enduring preconceptions about local ethnic particularities as by the generalising tendencies of the social sciences and racial preconceptions. The dissolute Haya and the broken Ganda family were stereotypes which shaped the discourse of local Europeans and Africans alike throughout the colonial period.

Medical workers should of course take some of the credit for the failure of society in Buganda and Buhaya to fall apart in the way that some of the analyses indicated it would. Mass STI treatment and African doctors' cultural advantages in the development of prevention messages reduced morbidity and sub-fertility in 1960s Buhaya. Simultaneously, in Buganda mortality among infants and toddlers due to gastroenteritis and kwashiorkor was reduced dramatically. As Jennifer Tappan has shown, these successes were driven in large part by the critically reflective nature of medical research. Around 1960, the prospect of imminent decolonisation caused some colonial scientists 
to think about the wider logic of Africanisation. A conference was held in 1961 which examined which aspects of indigenous culture could be adapted to help advance the prevention of malnutrition. A new awareness of the role of under-nutrition and infection in the development of kwashiorkor prompted a shift towards community-based medicine, integrating social workers, community development specialists and agricultural extension experts. Multidisciplinarity now focused on prevention and alleviation at the local level rather than on the construction of grand theories of causation. A recognition that health education had been amateurish and shaped by external preconceptions resulted in a deliberate foregrounding of African field staff in new nutritional programmes, whose vernacularisation of the message of a balanced diet, kitobero, proved remarkably successful. ${ }^{66}$ It seems that it was when significant investment in resources and research was combined with well-planned Africanisation that social diseases were most effectively challenged in this era.

\section{Acknowledgements}

This paper has benefited from the insights and support of Sunil Amrith, Felicitas Becker, Benedict Bigirwamungu, Emma Coombs, Asiimwe Godfrey, John Iliffe, Will Jackson, Charles Kahwa, Jesse Karugaba, Paul Lane, John Lonsdale, Gerald Lubega, Phillip Mbatya, Wilbert Mwandiki, Dr Mussa Ndyeshobora, Christine Ninsiima, Charles Otim, Jo Parish, Chris Prior, Syridion Rweyendere, Carol Summers, John Sutton, Yvonne Swai, and Hebe Welbourn; COSTECH, UNCST, the Red Cross, the Ministries of Health and the local administrations in Tanzania and Uganda; the AHRC, the British Academy, the British Institute in Eastern Africa, and the ESRC.

\section{Notes}

1 D. Arnold, Science, Technology and Medicine in Colonial India, Cambridge, Cambridge University Press, 2000; J. Comaroff, 'The Diseased Heart of Africa: Medicine, Colonialism, and the Black Body', in S. Lindenbaum and M. Lock (eds.), Knowledge, Power, and Practice: The Anthropology of Medicine and Everyday Life, Berkeley, California University Press, 1993, pp. 305-29; P. Curtin, 'Medical Knowledge and Urban Planning in Tropical Africa', American Historical Review, 90, 1985, pp. 594-613; S. Feierman and J. Janzen (eds.), The Social Basis of Health and Healing in Africa, Berkeley, California University Press, 1992; J. McCulloch, Colonial Psychiatry and 'The African Mind', Cambridge, Cambridge University Press, 1995; J. McGregor and T. Ranger, 'Displacement and Disease: Epidemics and Ideas about Malaria in Matabeleland, Zimbabwe, 1945-1996', Past and Present, 167, 2000, pp. 203-38; Bertrand Taithe and Katherine Davis, '"Heroes of Charity?' Between Memory and Hagiography: Colonial Medical Heroes in the Era of Decolonisation", The Journal of Imperial and Commonwealth History, 42, 5, 2014, 


\section{BEYOND THE STATE}

pp. 912-35; M. Vaughan, Curing Their Ills: Colonial Power and African Illness, Cambridge, Polity Press, 1992

2 This paper will use Haya and Ganda to refer to the peoples who lived in Buhaya and Buganda, and also as an adjective to describe them.

3 For examples of growing non-racialism, particularly in Uganda, see for example 'British Contributions to Medical Research and Education in Africa after the Second World War', A Witness Seminar held at the Wellcome Institute for the History of Medicine, London, on 3 June 1999, http://www2.history.qmul.ac.uk/research/modbiomed/Publications/wit_vols/44832.pdf, pp. 9-10; J. Iliffe, East African Doctors, Cambridge, Cambridge University Press, 1998, pp. 142-4. For discussion of the tendency to pathologise African culture, see J. Lonsdale, 'Mau Maus of the Mind: Making Mau Mau and Remaking Kenya', Journal of African History, 31, 3, 1990, pp. 393-421. For an example see J. Carothers, The African Mind in Health and Disease: A Study in Ethnopsychiatry, Geneva, World Health Organization, 1953

4 D. Schoenbrun, 'Cattle Herds and Banana Gardens: The Historical Geography of the Western Great Lakes Region, ca AD 800-1500', The African Archaeological Review, 11, 1993, pp. 39-72, at 50-3; B. Lejju, P. Robertshaw and D. Taylor, 'Africa's Earliest Bananas?', Journal of Archaeological Science, 33, 1, 2006, pp. 102-13

5 P. Kollman, The Victoria Nyanza: The Land, the Races and their Customs, with Specimens of some of the Dialects, London, Swan Sonnenschein, 1899, p. 68; H. Rehse, Kiziba: Land und Leute, Stuttgart, Strecker und Schröder, 1910, p. 2

6 R. Austen, Northwest Tanzania under German and British Rule: Colonial Policy and Tribal Politics, 1889-1939, New Haven, CT, Yale University Press, 1968; A. Culwick and G. Culwick, ed. V. Berry, The Culwick Papers 1934-1944: Population, Food and Health in Colonial Tanganika, London, Academic Books, 1994, p. 262; B. Larsson, Conversion to Greater Freedom? Women, Church and Social Change in North-Western Tanzania under Colonial Rule, Uppsala, University of Uppsala, 1991, pp. 92-114

7 A. Southall and P. Gutkind, Townsmen in the Making: Kampala and its Suburbs, Kampala, EAISR, 1957, pp. 82-3

8 M. Koku and M. Ngaiza, 'The Life History of a Housewife: Her Life, Work, Income and Property Ownership', in M. Ngaiza and B. Koda (eds.), Unsung Heroines: Women's Life Histories from Tanzania, Dar es Salaam, WRDP, 1991, pp. 85-108, at p. 92; Tanzania National Archives (TanNA) 1733/3:46 AB40, Bukoba District Annual Report (BDAR) 1925, p. 3

9 TanNA 1733/8 AB10, BDAR 1923

10 TanNA 1733/8 AB10, BDAR 1923; TanNA 1733/3:46 AB40, BDAR 1925 Bukoba sub-district.

11 Culwick and Culwick, ed. Berry, The Culwick Papers, p. 173 (quoting the 1937 annual district medical report); TanNA 215/2237, Annual Report for the Bukoba District for the year 1948; W. Laurie and H. Trant, East African Medical Survey, Monograph no. 2: A Health Survey in Bukoba District, Tanganyika, Nairobi, EAHC, 1954, p. 142

12 TanNA 1733/3:46 AB40, BDAR 1925 Bukoba sub-district; TanNA 215/77/B, BDAR 1928; Tanganyika Territory, Annual Medical Report 1928, TanNA Library; Culwick and Culwick, ed. Berry, The Culwick Papers, p. 173; Tanganyika Territory, Annual Medical report 1938, Dar es Salaam, Government Printer, 1940; Tanganyika Territory, Annual Report of the Medical Department 1941, Dar es Salaam, Government Printer, 1942; Tanganyika Territory, Annual Report of the Medical Department 1943, Dar es Salaam, Government Printer, 1944

13 W. Young, 'Extra-urethritic Cases in an African Venereal Diseases Hospital', The British Journal of Venereal Diseases, 20 1944, pp. 151-4, 143-4; Laurie and Trant, East African Medical Survey, pp. 119-34

14 Bahaya is the linguistically correct form of the name of the people of Buhaya. The term is now usually shortened in academic writing to Haya

15 E. Huxley, The Sorcerer's Apprentice, London, Chatto and Windus, 1948, pp. 191-3

16 McCulloch, Colonial Psychiatry, pp. 46-7; J. Sadowsky, Imperial Bedlam: 


\section{COLONIAL MEDICAL SERVICE IN TANGANYIKA AND UGANDA}

Institutions of Madness in Colonial Southwest Nigeria, Berkeley, University of California Press, 1999, pp. 99-100; Vaughan, Curing Their Ills, pp. 57, 107-8, 135. For contemporary examples see H. Gordon, 'The Mental Capacity of the African', Journal of the Royal African Society, 33, 1934, pp. 226-42; M. Field, 'Mental Disorder in Rural Ghana', The Journal of Mental Science, 104, 1958, pp. 1043-51; H. Shelley and W. Watson, 'An Investigation Concerning Mental Disorder in Nyasaland', Journal of Mental Science, 82, 1936, pp. 701-30

17 F. Lugard, The Dual Mandate in British Tropical Africa, Edinburgh, Blackwood, 1922

18 A. Richards, Land, Labour, and Diet in Northern Rhodesia: An Economic Study of the Bemba Tribe, Oxford, Oxford University Press, 1939. See M. Watts, Silent Violence: Food, Famine and Peasantry in Northern Nigeria, Berkeley, University of California Press, 1983 for a more recent discussion along similar lines.

19 Cf. C. Prior, Exporting Empire: Africa, Colonial Officials and the Construction of the British Imperial State, c.1900-39, Manchester, Manchester University Press, 2013

20 TanNA 1733/3:46 AB40, BDAR 1925; Tanganyika Territory, Department of Agriculture Annual Report, 1932, Dar es Salaam: Government Printer, 1933; G. Milne, 'Bukoba: High and Low Fertility on a Laterised Soil', The East African Agricultural Journal, 4, 1938, pp. 1-21, at pp. 14-15; TNA 215/1650, Lake Province Annual Report 1940; TNA 215/2237, BDAR 1948; D. McMaster, 'Change of Regional Balance in the Bukoba district of Tanganyika', Tanganyika Notes and Records, 56, 1961, pp. 79-92, at pp. 89-91

21 University of Dar es Salaam (UDSM), East Africana Collection, Cory Manuscripts (EAF.Cory) 104 Bukoba, H. Cory, 'The Haya Tribe and the Incidence of Venereal Disease, Bukoba 1938-48', typescript, p. 7. For further discussion of the frequently negative, and occasionally sexualised, depictions of African landscapes, see D. Hammond and A. Jablow, The Africa that Never Was: Four Centuries of British Writing about Africa, New York, Twayne, 1970

22 TanNA 215/2154, BDAR 1947; T. Harris, Donkey's Gratitude: Twenty-two Years in the Growth of a New African Nation - Tanzania, Durham, Pentland Press, 1992, pp. 235-7, 261, 266; TanNA 1733/8 AB10, BDAR 1923; TanNA 215/77/B, BDAR 1928; TanNA 215/2510, BDAR 1951; Larsson, Conversion, pp. 90, 105. Cf. Prior, Exporting Empire

23 The Culwicks had collaborated on one of the most important studies of population decline in interwar Africa, their analysis being based on life histories provided by 2,300 women. A. Culwick and G. Culwick, 'A Study of Population in Ulanga, Tanganyika Territory', The Sociological Review, 30, 1938, pp. 365-79

24 UDSM, EAF.Cory 239 Bukoba, A. Culwick, 'The Population Problem in the Bukoba District', 1938, pp. 7-9

25 UDSM, EAF.Cory 104 Bukoba, Cory, 'The Haya tribe', p. 1; Culwick and Culwick, ed. Berry, The Culwick Papers, pp. 124, 174-7, 228-9; UDSM, EAF.Cory 239 Bukoba, Culwick, 'The Population Problem', pp. 29-35, 41, 66. For a discussion of the colonial tendency to view social problems through a psycholanalytical lens, see W. Anderson, D. Jenson and R. Keller (eds.), Unconscious Dominions: Psychoanalysis, Colonial Trauma, and Global Sovereignties, Durham, NC, Duke University Press, 2011

26 UDSM, EAF.Cory 104 Bukoba, Cory, 'The Haya Tribe', pp. 9-19

27 TanNA 215/2237, BDAR 1948

28 East African Medical Survey, Annual Report, 1952, Nairobi EAHC, 1953, pp. 23-32; East African Medical Survey, Annual Report, 1953, Nairobi, EAHC, 1954, pp. 12-13; Laurie and Trant, East African Medical Survey, pp. 1-4, 138-40

29 TanNA 215/77/B, BDAR 1928; Culwick and Culwick, ed. Berry, The Culwick Papers, p. 173; UDSM EAF.Cory 21, Bukoba, District Commissioner to Provincial Commissioner, 10 April 1951; W. Laurie, 'A Pilot Scheme of Venereal Disease Control in East Africa', British Journal of Venereal Diseases, 34, 1958, pp. 16-21, at p. 21 


\section{BEYOND THE STATE}

30 Iliffe, East African Doctors, p. 40; TanNA 215/2237, BDAR 1948; TNA 215/2237, BDAR 1948; TNA, 215/2070, BDAR 1946

31 TanNA 31732, A.R.M. for Director of Medical Services to Chief Secretary, 18 October 1943, Minute 2, Yaws

32 UDSM, EAF.Cory 104 Bukoba, Cory, 'The Haya Tribe', p. 10; Culwick and Culwick, ed. Berry, The Culwick Papers, pp. 44-50; UDSM, EAF.Cory 239 Bukoba, Culwick, 'The Population Problem', p. 9. Cf. TNA 215/2237, BDAR1948

33 Harris, Donkey's Gratitude, pp. 261-5; USDM EAF.Cory 21, Bukoba, 1950-8, DC to PC, 10 April 1951

34 Rhodes House Library, Oxford (RHL), MSS.Afr.s.1872143, H. Trant, 'Not Merrion Square: Anecdotes from a Woman's Medical Career in Africa', p. 128; Laurie, 'A Pilot Scheme', p. 18; Laurie and Trant, East African Medical Survey, pp. 4-5

35 Interview (Int.) HL, Maruku, M, 6, 17 June 2000. Interviewees' names have been coded to protect their anonymity. Transcripts are available for consultation from the author.

36 Laurie and Trant, East African Medical Survey, pp. 135-41; USDM EAF.Cory 21, Bukoba, 1950-8, DC to PC, 10 April 1951; Int. HL, Maruku, M, 6, 17 June 2000; Int. JBK, Ijumbi, 11 August 2000, M; TNA/215/2700, BDAR 1953; TanNA, Acc.71 M.1/1 Medical general, Vol. 2, District Medical Officer to Provincial Medical Officer, Monthly report, West Lake, May 1957, 6 June 1957; TanNA/967.822.1, West Lake Provincial Annual Report 1960; TanNA/215/3449, BDAR 1957; Iliffe, East African Doctors, pp. 106-7

37 C.Mtawali, 'A Health Campaign in Tanganyika Territory', Community Development Bulletin, 2, 1951, pp. 54-6

38 Int. VK, Bukoba, 27 June 2000

39 Mwanza Archives, MISS/DN/53, Annual Report Bukoba District Council Medical Services, 1966, 30 January 1967; R. Henin, National Demographic Survey of Tanzania, 1973: Volume II, Data for Socioeconomic Groups, Dar es Salaam, Tanzania Bureau of Statistics, 1973, pp. 78, 32

40 P. Reining and A. Richards, 'Report on Fertility Surveys in Buganda and Buhaya, 1952', in F. Lorimer et al. (eds.), Culture and Human Fertility, Paris, UNESCO, 1954, pp. 351-404. Cf. P. Reining, 'The Haya: The Agrarian System of a Sedentary People', unpublished PhD dissertation, University of Chicago, 1967, pp. iv, 75-8, $131-6,315-20$

41 D. Jelliffe, 'Village Level Feeding of Young Children in Developing Tropical Regions, with Especial Reference to Buganda', Journal of the American Medical Women's Association, 17, 5, 1962, pp. 409-18, at p. 413.

42 The best examples of these genres are H. Johnston, The Uganda Protectorate, London, Hutchinson, 1902; J. Roscoe, The Baganda: An Account of Their Native Customs and Beliefs, London, Macmillan, 1911; A. Kaggwa, The Customs of the Baganda, trans. E. Kalibala, ed. M. Edel, New York, Columbia University Press, 1934

43 See in particular L. Mair, An African People in the Twentieth Century, London, Routledge, 1934; Southall and Gutkind, Townsmen in the Making; L. Fallers (ed.), All The King's Men: Leadership and Status in Buganda on the Eve of Independence, London, Oxford University Press, 1964; A. Richards, The Changing Structure of a Ganda Village: Kisozi, 1892-1952, Nairobi, EAPH, 1966; M. Ainsworth, Infancy in Uganda: Infant Care and the Growth of Love, Baltimore, Johns Hopkins Press, 1967

44 C. Summers, 'Radical Rudeness: Ugandan Social Critiques in the 1940s', Journal of Social History, 39, 3, 2006, pp. 741-70. Mailo derives from square miles, referring to the size of the hereditary estates allocated to Buganda's elite in 1900.

45 M. Worboys, 'The Discovery of Colonial Malnutrition between the Wars', in D. Arnold (ed.), Imperial Medicine and Indigenous Societies, Manchester, Manchester University Press, 1988, pp. 208-25, at pp. 210-11

46 H. Trowell et al., Kwashiorkor, 2nd edn., London, 1982, pp. xxv, 246; RHL MSS. Afr.s.1872/xxxiv, H. Trowell, 'Transcription of interview', 1982, 19 
47 C. Williams, 'Kwashiorkor: A Nutritional Disease of Children Associated with a Maize Diet', Lancet, 16 November 1935, pp. 1151-2

48 RHL MSS.Afr.s.1792/45, M. Southwold, 'Ganda Conceptions of Health and Disease', Symposium on Attitudes to Health, typescript, 1959, pp. 43-6,

49 H. Welbourn, 'The Danger Period during Weaning. A Study of Baganda Children Who Were Attending Child Welfare Clinics near Kampala, Uganda', unpublished MD dissertation, University of Birmingham, 1952

50 Welbourn, 'The Danger Period', pp. 1-56

51 See, for example, J. Davies, 'The Essential Pathology of Kwashiorkor', The Lancet, $1948,1(6496)$, pp. 317-20

52 J. Tappan, "'A Healthy Child Comes from a Healthy Mother": Mwanamugimu and Nutritional Science in Uganda, 1935-1973', unpublished $\mathrm{PhD}$ dissertation, Columbia University, 2010, pp. 78-105

53 For an excellent discussion of the larger story of kwashiorkor see Tappan, "'A Healthy Child"', pp. 99-109, 275-7. As she notes, environmental factors did in fact remain a significant area of research, given the emphasis placed on the structural limitations of protein availability in the Ugandan diet.

54 For a discussion of the evolving understanding of this theme within Africanist anthropology see A. Kuper, Anthropology and Anthropologists: The Modern British School, London, Routledge \& Kegan Paul, 1983; L. Shumaker, Africanizing Anthropology: Fieldwork, Networks, and the Making of Cultural Knowledge in Central Africa, Durham, NC, Duke University Press, 2001, pp. 79, 155-6

55 See, for example, F. Cooper, On the African Waterfront: Urban Disorder and the Transformation of Work in Colonial Mombasa, New Haven, CT, Yale University Press, 1987; N. Hunt, A Colonial Lexicon of Birth Ritual, Medicalization and Mobility in the Congo, Durham, NC, Duke University Press, 1999; M. Shannon, 'Rebuilding the Social Life of the Kikuyu', African Affairs, 56, 1957, pp. 272-84; M. Sorenson, Land Reform in the Kikuyu Country, Nairobi, Oxford University Press, 1967

56 See S. Doyle, Before HIV: Sexuality, Fertility and Mortality in East Africa, 19001980, Oxford, Oxford University Press and the British Academy, 2013, ch. 4

57 M. Geber and R. Dean, 'Psychological Factors in the Etiology of Kwashiorkor', Bulletin of the World Health Organization, 12, 3, 1955, pp. 471-5; Ainsworth, Infancy in Uganda, p. 1. Cf. J. Bowlby, Maternal Care and Mental Health, Geneva, 2nd edn., World Health Organization, Monograph Series, No. 2, 1952. Ainsworth observed that weaning was not always as abrupt as it was reputed to be.

58 M. Geber, 'The Psycho-Motor Development of African Children in the First Year, and the Influence of Maternal Behavior', Journal of Social Psychology, 47, 1958, pp. 185-95, at p. 194; Geber and Dean, 'Psychological Factors'; Ainsworth, Infancy in Uganda, p. 420

59 A. Richards, 'Traditional Values and Current Political Behavior', in L. Fallers (ed.), All The King's Men: Leadership and Status in Buganda on the Eve of Independence, London, Oxford University Press, 1964, pp. 294-335; Southall and Gutkind, Townsmen in the Making, pp. 66-7

60 These issues were also matters of concern in 1950s Britain, and to some degree anthropologists' research interests may tell us as much about their own social preoccupations as about the African societies they described.

61 Ainsworth, Infancy in Uganda; Geber and Dean, 'Psychological Factors', p. 475; H. Welbourn, Our Children, Kampala, Uganda Council of Women, n.d. [c.1960], p. 36; H. Welbourn, 'Weaning among the Baganda', Journal of Tropical Pediatrics, 9, 1, 1963, pp. 14-24; D. Jelliffe, H. Welbourn and F. Bennett, 'Child Rearing and Personal Development in Africa', unpublished typescript in the possession of Hebe Welbourn, n.d. [c.1961], pp. 19-20

62 RHL J MSS Afr. s. 1872146 Twohig papers, 'Malnutrition', memorandum written by J. Twohig, DMO Masaka, 1951; D. Jelliffe, 'The Need for Health Education', Report of a Seminar on Health Education and the Mother and Child in East Africa', Makerere Medical School, Kampala, November 1961, p. 1; Jelliffe, 'Village Level 


\section{BEYOND THE STATE}

Feeding'; H. Welbourn, 'Backgrounds and Follow-up of Children with Kwashiorkor', Journal of Tropical Paediatrics, 5, 4, 1959, pp. 84-95, at pp. 91-2. See Tappan, "'A Healthy Child"', pp. 178, 187-97 for a critical analysis of the limitations of medical assumptions that bottle feeding was, at core, driven by mimicry of Western modernity.

63 A. Hailey, An African Survey. A Study of Problems arising in Africa, South of the Sahara, 2nd edn., Oxford, Oxford University Press, 1957; H. Tilley, Africa as a Living Laboratory: Empire, Development, and the Problem of Scientific Knowledge, 1870-1950, Chicago, University of Chicago Press, 2011. See Shumaker, Africanizing Anthropology, pp. 69-71, 84 for a discussion of the Rhodes-Livingstone Institute's social scientists' imitation of the techniques and language of the laboratory, and their interaction with agriculturalists and ecologists. Its founder, Max Gluckman, argued that anthropologists should influence policy, be useful to government and contribute to development and public health.

64 Uganda Protectorate, Annual Medical Report, 1952, Entebbe, Government Printer, 1953; Women's Library, London, 3AMS/D/49, F. Webber, Colonial Office, to General Secretary Association for Moral and Social Hygiene, 30 October 1951, Uganda 1908-54; Int. HW, Bristol, 31 July 2008, F; A. Hastings, Christian Marriage in Africa, Being a Report Commissioned by the Archbishops of Cape Town, Central Africa, Kenya, Tanzania, and Uganda, London, SPCK, 1973

65 Tappan, "'A Healthy Child"', p. 118. Note that J.C. Carothers was admired for his humane treatment of the mentally ill in Kenya, yet depicted Africans as fundamentally immature, hypersexualised and incapable of logic or forward planning, due to the frontal lobes of their brains being 'functionally absent', the retarding consequences of endemic malnutrition and the damaging effects of African cultures, including childrearing practices. It should be assumed that social and medical scientists in 1950s Uganda would have read Carothers. Cf. Carothers, African Mind; J.C. Carothers, The Psychology of Mau Mau, Nairobi, Government Printer, 1954

66 Tappan, "'A Healthy Child"', pp. 133-4, 161-3, 219-27, 237, 243, 246, 272-7; D. Jelliffe, 'Custom and Child Health I', Tropical and Geographical Medicine, 15, 1963, pp. 121-3 